\title{
Modes of Governing Canadian Waste Management: A Case Study of Metro Vancouver's Energy-from-Waste Controversy
}

Scott Cameron Lougheed*

Jessica Metuzals ${ }^{*}$

Myra J. Hird ${ }^{*}$

* School of Environmental Studies, Queen's University, Kingston, Canada

Corresponding Author: Scott Cameron Lougheed, Queen's University, Biosciences Complex Room 3224, 116 Barrie St, Kingston ON K7L 3J9 Canada

Email: lougheed.scott@queensu.ca 


\title{
Modes of Governing Canadian Waste Management: A Case Study of Metro Vancouver's Energy-from-Waste Controversy
}

\author{
As landfilling costs increase and controversies emerge over new waste processing \\ facilities, managing growing quantities of municipal solid waste is a pressing \\ environmental and political concern for Canadian municipalities, who bear the primary \\ responsibility for coordinating waste management (WM). In 2015, Metro Vancouver's \\ plans to expand their capacity to manage their waste through energy-from-waste \\ technology was put on hold indefinitely despite shrinking landfill space and persistent \\ public opposition to new landfills. Using Bulkeley et al.'s (2005) 'modes of governing \\ framework', we analyze Metro Vancouver's failed attempt to expand their energy-from- \\ waste capacity to better understand the challenges associated with how waste is governed \\ in Canada. We argue that a history of downloading responsibility for WM to \\ municipalities, regional districts, and private industry has fragmented WM governance, \\ posing a challenge for developing new waste infrastructure. We find that this localization \\ of responsibility is incompatible with contemporary WM challenges. The scalar mismatch \\ between waste's material impacts and the scale at which waste is managed has resulted in \\ co-dependence and conflict between putatively independent municipalities, regional \\ districts, and private companies. As a result, both higher-level WM coordination is \\ inhibited while the autonomy of individual municipalities is simultaneously undermined.
}

Keywords: Municipal solid waste, governance, waste management, regional politics, incineration

\section{Introduction}

Mounting economic, political, and environmental concerns underlie emerging challenges in governing waste management (WM). The growing trend to conceptualize waste as a resource particularly as a source of energy and revenue - is encountering both strident proponents and opponents. While energy-from-waste (EfW) technology is well established across Europe with over 300 EfW plants there are only 6 such facilities in Canada (Giroux Environmental Consulting, 2014), despite growing evidence that members of the public now view incineration 
more favourably than landfilling (Baxter, Ho, Rollins, \& Maclaren, 2016; Lougheed, Hird, \& Rowe, 2016). While there was no shortage of opposition to EfW across the EU, various EUmandated initiatives (including the Landfill Directive in 1999) have pushed national and local governments away from landfilling and towards EfW (Bulkeley, Watson, \& Hudson, 2007; European Commission, 2016). In this paper, we use the modes of governing framework proposed by Bulkeley and colleagues $(2007 ; 2005)$ to better understand the institutional relationships and governance challenges faced by Metro Vancouver (MV), a large Canadian regional district in the province of British Columbia (BC), as it plots its waste future and the role energy from waste incineration facilities (EfW) will play in that future. Through this case study we seek to better understand the scalar struggles that attend neoliberal governance of WM specifically and of Canada more broadly. Our analysis of MV's institutional relations and conflict in the context of a proposed expansion of EfW capacity suggests that local and provincial governments have significant and diverse interests in the governance of WM. Consequently, within- and betweenscale disjunctures have emerged regarding WM strategies and subtending governing rationalities. Through this case study we argue that these disjunctures are indicative of broader issues associated with the decades-long devolution of responsibility for waste (among other things) to increasingly lower levels of government in Canada, and are emblematic of the extent to which urban governance and WM politics are inextricable and, indeed, co-constitutive (Boyle, 2002). Referring to WM in the UK, Bulkeley et al. (2007, p. 2750) suggest that the greater responsibility placed on local authorities has, in some exceptional cases, prompted these authorities to 'creatively redefine' WM which resulted in two potential outcomes: 1) the success or failure of governing to achieve its desired ends, such as the failure for a local authority to meet national and EU waste diversion targets; and 2) the local enrolment of new (typically non-state) 
governing actors such as waste haulers and charitable organizations to achieve waste diversion targets and eek out additional local social benefits. In this case, governing appears unproblematically generative of alternative modes of governing (they characterize these as 'ecoefficiency' and 'waste as a resource') as it encounters the idiosyncrasies of everyday practice and the variability of local values. We will argue that an underdeveloped aspect of these political dynamics concerns the way that this local creativity can result in significant friction (Star, 1995). Our aim is to explore is how such independence and creative capacity at the local level can result in conflicts both with other local authorities as well as with higher levels of government what Murdoch (2000, p. 510) refers to as 'spatial complexity'. This complexity results when moving from the abstract governing rationale and objectives established by higher levels of government to locally situated and contextualized practices, experiences, and values. As we show, in an expansion of the modes of governing framework, there can be considerable tension between the 'generality, reliability, and portability' of governing rationalities in the abstract, and the 'customization, uniqueness, [and] goodness of fit' of that rationality and the attending technologies in a given local context (Star, 1995, pp. 91-2; see also: Murdoch, 2000).

\section{Governing Municipalities, Governing Waste}

In contrast to the EU, WM responsibility and decision-making in Canada takes place primarily at the municipal or regional district level with little federal or provincial involvement beyond general regulations and guidelines (Darier, 1996a; Lougheed et al., 2016). In BC, individual, largely autonomous, regional districts formulate Integrated Solid Waste and Resource Management Plans (ISWRMP) that the province approves or denies based on their compliance with a broad set of provincial criteria. The provincial government has set a province-wide target to reduce per-capita residual waste (post-separation and diversion) to $350 \mathrm{~kg}$ from a current 
average of $520 \mathrm{~kg}$ by 2020 . Regional districts, while not bound to the provincial residual waste target, are required to establish their own targets that are 'realistic' given local conditions. Neither provincial or regional targets are binding and do not connect directly to any funding or fines. This regulatory 'softness' is meant to recognize the considerable variability in waste diversion across the province's regional districts, with per capita residual waste rates varying between $267 \mathrm{~kg} /$ person and $854 \mathrm{~kg} /$ person (Government of British Columbia, 2014a).

The governance of waste has undergone several transitions in Canada. Prior to the industrial revolution, individual cartage and disposal operators began to haul towns and cities' discarded objects away, introducing a new form of governance that emphasized waste's isolation from community life (Melosi, 2004). As the sheer volume and diversity of waste increased, much larger companies and eventually multinational corporations usurped small operators. These publicly traded corporations invested heavily in all aspects of waste's management: indeed, they have been instrumental in defining waste as something that can and should be managed (as opposed to decreased) (Hird, 2015). Simply put, waste is big business, and Canadian municipalities increasingly work with, and indeed depend upon, WM companies to deal with all facets of waste processing, from waste technology assessment, siting, construction, operations and monitoring to closure, and aftercare. Working with local governments, these WM companies increasingly manage public discussions of WM through feasibility reports, town hall meetings, presentations, and other forms of prescribed consultation (Allen, 2007; Carse, 2012; Marres, 2005; Van de Poel, 2008). Indeed, neoliberal governance enhances industry's monopoly by embedding techniques such as public consultations, and feasibility studies within industry's remit. In other words, geo-engineering and economics are the primary discourses through which 
modern WM operates (for an expanded explanation see Hird, Lougheed, Rowe, \& Kuyvenhoven, 2014).

It is of vital social scientific interest, therefore, to better understand how current neoliberal governance, and specifically the devolution of governing waste to regional districts and municipalities, creates significant challenges to the development of future WM and waste infrastructure (see also: Lougheed et al., 2016). In what has been called a 'governance turn' (Chhotray \& Stoker, 2010, p. 7) over the last three decades, the concept of governance is now the focus of much social science research (Pierre \& Peters, 2000). Governing, broadly understood, refers to the methods through which collective action and decision making take place, typically as it relates to public affairs and policy development (Kooiman, 2003; Pierre \& Peters, 2000; Rhodes, 1996), while governance refers to the instituted processes through which governing takes place and is coordinated (Lowndes, 2001; Pierre \& Peters, 2000; Rhodes, 1996).

The move from the nation-state as the central pillar for directing or steering public affairs to a more variegated and decentralized set of actors and governing efforts has necessitated new ways of conceptualizing and analysing how society is governed (Hobson \& Hill, 2010; Rhodes, 1996). In Canada this has manifested in the devolution of environmental responsibility and rescaling many aspects of governing to increasingly lower levels of government and to individuals (Darier, 1996a; Lougheed et al., 2016). Following a broader neoliberal trend, the state is moving away from being a direct provider of social resources and services and increasingly moved towards a role of 'steering' and facilitating conditions favourable to the development of self-organizing governance networks that fulfil the role formerly occupied by the state (Dean, 2007; Murdoch, 2000; Rhodes, 1996). A shift towards analyses of governance is a response to the practical shifts in the practice of government. It attempts to move away from 
analyses of formal state institutions to account for a landscape or 'network' (Murdoch, 2000; Rhodes, 1996) increasingly comprised of diverse forms of governing by a variety of public and private entities across spatial and jurisdictional scales (Kooiman, 2003). The composition of governance networks is contingent on the scalar strategy employed for governing a given object such as waste. In the case of WM, the network is comprised of the provincial government who sets the broad environmental regulations and (non-binding) WM goals and regional districts, the primary level at which WM is scaled, who devise and implement strategies to reach these goals or local interpretations thereof - in partnership with residents and private corporations (in addition to an inexhaustible list of others too extensive to catalogue for our purposes).

As these insights suggest, power is increasingly diffused and distributed across a semistable network of state- and non-state actors (Chhotray \& Stoker, 2010; Kooiman, 2003; Pierre \& Peters, 2000) comprising multiple interrelated 'regimes of practice' that include managing waste, economic growth, securing borders, curing illness, and so on (Dean, 2009). For example, WM impacts other institutions such as those that govern economic growth: in 2012 the WM industry in Canada generated six billion dollars in revenue, up nearly 50\% from 2004, and employed nearly 30,000 people (Statistics Canada, 2015). The (re)production of these governance networks and the regimes of practice they subtend requires work, maintaining a balance between autonomy of governing actors on the one hand, and integration on the other, such that no institution or local actor diverges to an extent that undermines the broader governing aims of the network, such as those established by state authorities (Murdoch, 2000).

Beyond a recognition that Canadian WM has devolved to local government, which in turn has developed complex relationships with multinational corporations, there is much more to be understood about the dynamics of how WM is governed in Canada; specifically, the local 
context in which WM is coordinated within a broader network of governance. Bulkeley et al. (2005) propose an analytical framework that recognizes how policy forms within and because of shifting social, cultural, economic, and political contexts. A mode of governing is 'a set of governmental technologies deployed through particular institutional relations through which agents seek to act on the world/other people in order to attain distinctive objectives in line with particular kinds of governing rationality' (Bulkeley et al., 2007, p. 2739). The concept of a governing rationality is defined as a set of principles, expertise, or framings that shape how the conduct of individuals or collectivities are to be guided (Dean, 2009; Gordon, 1991). Each mode of governing can be characterized by a certain governing rationality; the specific governing agents involved; the institutional relations between agencies; the governmental technologies such as policies and programs put in place; and the human and nonhuman entities that are governed (Bulkeley et al., 2007). Modes can coexist, are dynamic, and are flexible over time and space. For instance, governmental rationalities can shift if governed entities resist or problematize existing modes; if governmental technologies fail to be implemented or are implemented in unexpected ways comport with locally embedded meaning and experience but diverge from more broadly established governing aims; or if the power and authority of governing agencies is reconfigured (Bulkeley et al., 2007).

The following sections explore how WM in Canada, governed almost exclusively at the local level, has resulted in a fragmented landscape of 'competing rationalities' (Howell, 2015, p. 2157). As regional districts attempt to redefine WM in their local context, these locally constructed rationalities overlap, intersect, and are contested. We argue that this highlights a major challenge for WM in Canada, and is perhaps indicative of current and future issues with Canada's contemporary neoliberal governance. It is therefore imperative that analyses of 
governance are sensitive to these dynamics of governance, and recognize that multiple governing goals and means of achieving these goals may coexist (Bulkeley et al., 2007; Dean, 2009) and as we show below, may result in conflict. To that end, we employ the modes of governing framework for the sensitivity it offers to these dynamics of governance to elucidate the impacts of neoliberalized WM. By applying this framework to the case of WM in MV, we seek to further enhance its utility, specifically as it relates to the emergence of conflicts in governance.

\section{Metro Vancouver's Waste Governance}

Metro Vancouver (MV) consists of 21 municipalities and manages over 1.3 million tonnes of MSW annually (Metro Vancouver, 2013). MV's current waste disposal system includes the Vancouver Landfill operated by the City of Vancouver, the Cache Creek Landfill operated by the private company Belkorp, and an EfW facility owned by MV and operated by Covanta (another private company). MV is responsible for providing waste disposal services for the municipalities under its remit. MV generates revenue from its own EfW facility and transfer stations through tipping fees, which is a cost-per-ton paid to the operator of the facility to dispose of material there. However, MV also relies heavily on landfills, transfer stations, and transport provided by others, the cost of which far outweighs the revenue MV earns from its own infrastructure. For example, in 2014, solid waste tipping fees generated \$89.2 million in revenue for MV, yet in the same year MV spent over \$100 million dollars on MSW management overall (Metro Vancouver, 2014c). Private waste haulers exporting waste out of the region, a rapidly growing trend, has contributed to this revenue shortfall.

Like other Canadian municipalities, MV responded to dwindling landfill space and increasing costs by initiating an ambitious waste diversion campaign and proposing an expansion of EfW capacity concurrent with this diversion campaign (Government of British Columbia, 
2014b; Metro Vancouver, 2010; for case studies in other Canadian municipalities see: Hird et al., 2014; Lougheed et al., 2016). Significant opposition to previous proposals to expand the region's two landfills and the proposal to increase the region's EfW capacity put the proposals on hold. Thus, the future of WM in the MV region is both uncertain and embedded in a complex set of conflicting stakeholder interests.

Since 1966, the City of Vancouver has owned and operated the Vancouver Landfill, with additional waste sent to the Cache Creek Landfill, controlled by the village of Cache Creek (pop. 1040) and Wastech Services (a Belkorp Subsidiary), located 340 kilometres east of MV (Metro Vancouver, 2007). The Cache Creek Landfill is contracted to serve MV who reserves the right to deny any other municipality access to the landfill. The Village of Cache Creek receives royalties based on the total tonnage disposed, which has had a profound positive economic impact on the community. Because of these subsidies, their long-term debt has been eliminated, overall revenues have increased for local government, and property taxes have decreased (Urban Systems, 2002).

In 2010, the B.C. government approved a pair of expansions to the Cache Creek Landfill proposed by the village and the landfill operator Wastech, extending its life as a source of revenue for the town of Cache Creek by up to 25 years and making the landfill accessible to all municipalities (Sinoski, 2010). Meanwhile, as part of a broader strategy to localize waste processing, MV proposed an aggressive goal to increase their EfW capacity by up to 500,000 tonnes by 2015, effectively replacing their reliance on the Cache Creek Landfill and on exporting waste to Washington State (Metro Vancouver, 2010). From its inception, the proposal was divisive among different levels of government, local governments and residents in adjacent regions, and industry. In December of 2015, MV announced that it was halting plans to build a 
new EfW facility citing concerns about uncertain future waste volumes due to improved waste reduction and recycling efforts (Nagel, 2015).

\section{Disposal Mode}

The disposal mode is informed mainly by the rationalities of economic efficiency, with only superficial concern for broader public health and environmental issues (Bulkeley et al., 2007). Within this mode, waste is conceptualized as something to be rid of in the most economically efficient way. This is reflected by the emphasis on economic concerns demonstrated throughout the 1980s, which may in part be due to the heavy involvement of private firms and an underdeveloped concern for waste's environmental impact. Prior to, and for much of the 1980s, the Greater Vancouver Regional District (GVRD, later renamed Metro Vancouver) governed its waste through a disposal mode in which the central concern was cost. At the time, GVRD's solid WM system consisted of multiple small landfills across several municipalities. As these local landfills reached capacity, they were replaced with waste transfer stations where waste was 'repackaged' and shipped to larger and more economically efficient landfills (Henderson, 2004). Despite nascent public scrutiny of landfills (Roberts, 1982), the GVRD viewed landfilling as the least expensive, and thus optimal, way to deal with the region's waste. As such, at the time, EfW was dismissed as expensive and inefficient by GVRD officials (Roberts, 1982). The prevailing reliance on landfilling and attendant economic rationality was reinforced by the heavy involvement of private waste haulers whose primary concerns are economic rather than environmental.

Despite the ongoing prioritization of cheaper landfilling, the 1980s marked a transitional decade for WM governance as the environmental impacts of waste became of increasing public and government concern. Critics of the GVRD's commitment to landfilling argued that, while 
landfilling was inexpensive, the region was ultimately ignoring the social and environmental costs associated with this WM practice (Roberts 1982). As concern for the environmental impacts of waste increased among local officials and the public, and problems with the disposal mode were increasingly recognized, new institutional relations were formed, and new governing technologies deployed to align with this new rationality (Bulkeley et al., 2007). The region indicated its intention to encourage individual households to recycle to limit the rising costs of landfilling, though no formal plan had yet been proposed and would not appear for nearly a decade. The region also revisited the potential for EfW to relieve growing pressure on landfill capacity (Roberts, 1982). These moves indicate the beginning of a shift in WM governing rationalities to include not only economic efficiency but also a nascent concern for minimizing environmental impacts.

Plans to reduce the reliance on landfilling had its critics. Some government officials raised questions about the financial soundness of the proposed EfW facility, noting that an incinerator would cost the region $\$ 50$ a ton even after recovering energy, while landfilling cost only \$20 per ton (Roberts, 1982). Moreover, concrete plans for recycling programs would require enrolling many additional stakeholders, which would take time and negotiations, new infrastructure, and new market connections. These critiques contributed to a new governing rationality that began to concern itself with the substantive problem of environmental harm. It also required new governing technologies to shape the conduct of both those who would object to the emergent environmental rationality, but also the conduct of consumers whose shoulders would bear the responsibility for minimizing the environmental harm of waste.

\section{Diversion Mode}

The diversion mode relies on governing technologies that presuppose an idealized neoliberal 
citizen who is responsible, capable, and receptive to waste 'best practices' education. Interestingly, and rather counter-intuitively, this idealized form of what could be called the 'diversion citizen' must maintain their level of everyday consumption in order to reduce WM costs and contribute to economic growth (Rutherford, 2007). Indeed, diversion messaging strongly emphasizes recycling first, reusing second, and reducing consumption last. Governing technologies designed for the diversion citizen include recycling targets, financial incentives, and education campaigns (Bulkeley et al., 2007; Hobson, 2006; Lougheed et al., 2016). Throughout the 1990s, MV integrated these types of governing technologies into its WM regime, specifically in the form of diversion targets and disposal bans.

Although challenges to the status quo began in the 1980s, the transition to a more clearly articulated diversion mode of governing did not take place until the 1990s when the province intervened. In 1989, the provincial government amended the Waste Management Act (now the Environmental Management Act) to require regional districts to submit by 1995 a solid waste management plan (SWMP) $)^{1}$ that emphasized reducing waste sent to landfills. In 1992, additional amendments to the Act expanded regional districts' responsibilities to include recyclable materials management (British Columbia Ministry of the Environment, 1994). The legislative changes to the British Columbia Waste Management Act in 1989 and 1992, while implicating higher levels of government into WM, ultimately legislatively formalized local governments' increased responsibility. This was part of a broader neoliberal trend emblematized in the federal government's publication of the Green Plan in 1991, a whitepaper ${ }^{2}$ formally indicating the devolution of environmental responsibility to local governments and to individual citizens (Darier, 1996b; Lougheed et al., 2016). 
In the early 1990s, in part to comply with the British Columbia Waste Management Act, the GVRD began to prioritize diversion, primarily by incorporating recycling into the ISWRMP required by the province (Henderson, 2004). In the WM plan the GVRD established a performance target of 50\% reduction in per capita residual waste disposal by 2000 (Metro Vancouver, 2013), which it nearly met by decreasing its residual waste by $48 \%$ (Henderson, 2004). The primary technologies of governance included the introduction of individual household recycling in 1990, the implementation of tipping fee surcharges on big, bulky items such as cardboard in 1997, and office paper and newspaper recycling in 1999 (Webb, 1999). Since then, MV has steadily increased its diversion rates but largely failed to meet subsequent diversion goals. As of 2014 MV achieved a diversion rate of 52\% for MSW, 43\% for ICI waste, and $75 \%$ for demolition and land-clearing waste, totalling 2,040,280 tons, or $61 \%$ of all waste types diverted from landfill and EfW (Metro Vancouver, 2014a). MV's current ISWRMP outlines diversion targets of $70 \%$ by 2015 , and $80 \%$ diversion by 2020 (MV, 2011). MV has since failed to reach its 2015 target, achieving a diversion rate of only $62 \%$ for that year (Saltman, 2017).

Currently, MV enforces disposal bans on waste classified as recyclable, subject to product stewardship laws, or wastes that are considered hazardous materials. ${ }^{3}$ As of 2015 , MV began using financial penalties to enforce a new organics disposal ban. Waste loads disposed of at MV-controlled landfills that contain more than $25 \%$ food scraps are charged an additional $50 \%$ to the cost of disposal. In this scheme waste is inspected at the time of landfill disposal, at which point the waste is heavily aggregated from many different sources. As such, WM companies and waste haulers bear the costs of exceeding the $25 \%$ threshold for organics. Municipalities and residents therefore only indirectly feel the financial impact of these 
disincentives as fines increase the operating costs waste haulers who then bill municipalities whose main funding comes from property taxes. Given their indirect nature, it remains to be seen how effective these bans will be as a mechanism for increasing diversion. Moreover, household and individual practices, recycling markets, local infrastructure, and product design have generally limited waste diversion. As Darier (1996b, p. 77) notes 'the shift toward a waste management system based on reduction, reuse and recycling requires the learning of a totally new procedure affecting the daily actions of the entire population', something that, after over two decades of recycling, has yet to be fully realized. As landfill space becomes increasingly expensive and scarce, diversion will remain a necessary component of ISWRMP for the foreseeable future alongside new modes of governing waste.

\section{'Creative redefinition' or conflict?}

The emergence of eco-efficiency and waste as a resource modes of governance in the UK is described by Bulkeley et al. (2007) as a creative redefinition of WM's rationality resulting in what Murdoch (2000) describes as 'competing rationalities' (see also: Howell, 2015). What was not explored in detail in their study was the extent to which the emergence of these alternative modes and attendant competing rationalities results from, or serve to produce, conflict. Boyle (2002, p. 186) contributes to this analysis in his study of WM in Ireland. In what he calls a 'cultural politics', the specific scaling of WM at the regional level establishes a backdrop upon which variable and sometimes contradictory meanings can be ascribed to waste, its management, and the requisite infrastructure, resulting in a 'culture war' as WM strategies within and between regions evolve, diverge, and potentially conflict.

The primary goal of MV's current ISWRMP is reduction and reuse, reflecting an ambition to move beyond conventional diversion strategies (i.e. recycling) emphasized by the 
provincial government and MV's own past ISWRMPs. Only after reuse and reduction are exhausted would residual material be diverted to energy recovery technologies such as EfW or landfill (Metro Vancouver, 2010). ${ }^{4}$ There are two central mechanisms through which this proposal is being pursued: Extended Producer Responsibility (EPR) and Expanded EfW. MV has advocated for the B.C. government to continue its expansion of EPR as a means of further relieving local government of the burden of WM:

The costs and responsibilities of waste management have historically been borne by local governments and taxpayers. The responsibility for the costs and risks to manage end-of-life products should progressively transfer to the manufacturers of goods and consumers that use them and to provide appropriate market mechanisms to encourage more sustainable manufacturing and consumer choices. (Metro Vancouver, 2010, p. 16)

EPR is handled by provincial legislation, and the B.C. government has steadily expanded the range of products subject to EPR since 2004. The primary means by which this has been pursued is through product stewardship. Mirroring the requirement for regional districts to submit solid waste management plans to the province for approval, companies producing products in a growing list of categories (e.g., beverage containers, antifreeze, electronics, pesticides, lead-acid batteries pharmaceuticals) must provide the government with stewardship plans for approval. These plans must outline the procedures by which recovery and reuse will take place, current and projected recovery rates, and any third-parties operating on behalf of the producer to recover product.

The provincial government does not directly provide product stewardship, rather government serves as a facilitator of stewardship by industry by legislating which products are to be covered and creating favourable conditions to stewardship markets. In many cases, actual stewardship is handled by 'stewardship companies', typically operating as not-for-profit 
enterprises on behalf of categories of producers (rather than for any single producer). Encorp, for example, is responsible for beverage container recovery, operating 'Return-It' depots across the province where consumers can return their beverage containers. As a governing rationality, the stewardship model of EPR continues to shunt responsibility from local and provincial governments onto the market and manufacturers (and households who continue to be responsible for sorting their wastes and bringing that waste to the appropriate depots for processing).

EPR has been taken up by the province with little resistance from regional districts. In contrast, MV's proposal to expand EfW as a mechanism for recovering value from residual waste has been considerably more controversial. While MVs current ISWRMP emphasizes waste minimization over and above diversion - a goal shared by other regional districts - how MV has decided to act on this understanding of waste reveals divergent interests and conflicting visions for how this can be best achieved. There are two ways in which this conflict manifests: conflict between scales of government, in this case between the B.C. provincial government and MV over waste export, and between local stakeholders and adjacent regional districts over EfW.

As described above, within-region landfilling in MV is subject to numerous bans on certain materials and a tipping fee of $\$ 108$ per tonne. These restrictions and fees have prompted numerous waste haulers to bypass local facilities and export waste to Washington State where they pay $\$ 70$ per tonne and are subject to fewer restrictions (Bula, 2014a). MV estimates that since 2012, the amount of exported waste has nearly doubled and is expected to increase without legislative intervention to limit or ban waste export (Bula, 2014a). MV claims the fee structure and restrictions that have prompted this waste export are designed to encourage diversion and waste reduction, and the tipping fees fund several aspects of the region's WM system. But ongoing and growing waste export has two significant and interrelated negative implications for 
MV's current WM objectives. First, it increases costs for other users of local facilities by reducing the amount of waste being disposed of locally, and thus decreases revenue earned through tipping fees. MV officials estimate that between 2012 and 2014 over ten million dollars in revenue were lost to waste export (Bula, 2014a). This creates numerous problems. The increased tipping fees needed to compensate for lost revenue at local WM facilities has priced out smaller local waste haulers who are unable to ship their waste out of region to less expensive landfills. And because out-of-region landfills do not have the same material bans that MVcontracted landfills do, potentially divertible wastes end up in landfill anyway (albeit geographically displaced), contribute to greater transportation-related emissions, and the fate of the wastes cannot be reliably documented and included in performance targets such as diversion rates to measure the performance of the waste system (used, for example, to demonstrate program effectiveness to the provincial government and to justify landfill expansions or EfW proposals). With lower throughput in the local recycling and composting system, the long-term economic viability of that infrastructure is threatened and ultimately undermines landfill diversion attempts and increases the overall negative environmental impacts of MV's waste (Metro Vancouver, 2014b). A further consequence is that the rapid growth in waste export since 2010 has reduced the quantity and predictability of residual waste, which also jeopardizes the viability of the proposed EfW facility (Crittenden, 2014).

In 2014, MV recommended bylaw 280 to prevent the transportation of waste out of the region. MV argued that it would increase revenue for local government, improve waste diversion, and reduce overall infrastructure costs (Metro Vancouver, 2014b). This, MV contended, would benefit the region's WM performance targets and the economic viability of the existing WM infrastructure, while simultaneously providing a consistent and reliable waste 
stream for its previously proposed EfW facility. Tipping fees are MV's largest source of revenue at transfer stations and the Burnaby EfW facility. As such, MV argues that controlling the flow of waste through the implementation of bylaw 280 would have revenue-generating effects for the region (Metro Vancouver, 2013).

Critics of the proposed bylaw included Belkorp and other waste haulers, provincial politicians, the Vancouver Board of Trade, and politicians from the neighbouring Fraser Valley Regional District (FVRD) where Belkorp operates numerous transfer stations where waste exported from MV is transferred to trains destined for Washington State landfills. This group of opponents hired a high-profile lobbyist to fight the proposed bylaw (Bula, 2014a, 2014b), arguing that the proposed bylaw would create a WM monopoly controlled by MV. Such a monopoly, they feared, would dismantle the private sector and the current market-led WM system, which they argue would be increase service costs and thus, taxes. The BC Chamber of Commerce referred to bylaw 280 as 'extreme' in the extent to which it would impose price controls on the WM sector. Since MV is itself a waste service provider and WM regulator, the Chamber of Commerce identified it a 'significant' conflict of interest (BC Chamber of Commerce, 2016, p. 30). The general sentiment was that bylaw 280 was justified as a way to 'feed a \$500-million incinerator nobody wants' (Bula, 2014b, n.p.), and which was 'proven to be inefficient and expensive' (BC Chamber of Commerce, 2016, p. 30). Moreover, the Chamber of Commerce used bylaw 280 to question the amount of governing authority granted to regional districts, stating that instituting the bylaw was overstepping the scope of their authority, ultimately putting them at odds with industry and the interests of the municipalities that comprise the regional district (BC Chamber of Commerce, 2016). In the end, according to MV chair Greg Moore, the lobbying campaign led by Belkorp, Progressive Waste, and other WM companies 
was successful in persuading the provincial government to officially oppose bylaw 280 (Pynn, 2014).

Bylaw 280 exemplifies how the disposal, diversion, and emergent local modes have coalesced to form a fragmented waste governance landscape informed by different stakeholder rationalities across governing scales (Howell, 2015). Attempts to prevent the passing of bylaw 280 are indicative of the work needed to stabilize governance networks and prevent local actors from 'going their own way' (Murdoch, 2000, p. 514). In other words, local actors need just enough autonomy to govern according to locally emergent meanings and contexts, but not too much that they diverge too far from broader governing goals, such as those established by the provincial government. Subsequent to rejecting bylaw 280, the province reiterated its desire to see local governments 'establish and enforce disposal bans' (Government of British Columbia, 2015 , n.p), which was one of bylaw 280's explicit goals. However, because bylaw 280 was seen by the province and other regional governments as primarily a means to justifying expanded EfW, the aspects of the bylaw devoted to enhancing diversion and disposal bans were dismissed by its critics. MV's governing authority was ultimately challenged from above and below.

There is a scalar disconnect between responsibility for regulating, and actually handling, waste (Lougheed et al., 2016). While MV is charged with the responsibility for disposing of waste produced in the region, the province has denied it the ability to impose waste flow control measures. Opposition to the bylaw was heavily influenced by industry at both provincial and local levels. It also reflects a reassertion of the diversion mode that contrasted with MV's desire to move beyond diversion towards minimization and energy recovery. Indeed the campaign led by some industry actors, the FVRD, and the Chamber of Commerce to preserve competitive market dynamics at the potential expense of maximizing waste diversion suggests a subtle 
orientation towards regulating for the market in a way that resembles what has been referred to as the 'regulatory capture by industry' (Petts, 1998, p. 316). That is, private companies, largely motivated by economic interests, support out-of-region waste disposal as the most cost-effective option, something local and provincial stakeholders were unwilling to allow MV to disrupt.

While other local authorities, including the neighbouring FVRD and the village of Cache Creek, have shown a desire to move beyond basic diversion, these shared rationalities have led to different proposals for how such a goal could be achieved. The role that EfW should play in serving a governing rationality that extends beyond diversion, is particularly contentious. Belkorp and the village of Cache Creek opposed the possibility of EfW in MV for many of the same reasons they opposed bylaw 280; it would negatively impact revenue from the Cache Creek landfill. In 2009, Belkorp (who operates the Cache Creek landfill) hired the consulting firm KPMG to prepare a report comparing the economic costs of expanded EfW to the cost of the continued use of the Cache Creek Landfill. This report was highly critical of an earlier financial assessment conducted on behalf of MV that supported the EfW proposal. The new assessment prepared by KPMG on behalf of Belkorp claimed that unlike EfW, the costs of current landfill practices are known, predictable, and stable. Additionally, KPMG emphasized that the costs of 'new' technologies are relatively unknown, difficult to define, and therefore entail greater financial risks compared to landfilling. The report further highlighted how the economic viability of EfW could be affected by potential changes in both energy markets and the regulatory environment (Levelton Consultants Ltd, 2009).

In 2014, Belkorp once again commissioned an independent analysis of MV's Business Case for the proposed EfW facility. The report, released a week after bylaw 280 was rejected, stated that MV's Business Case underestimated its total project costs and predicted that the 
facility would cost the region $\$ 1.18$ billion dollars, $18 \%$ greater than MV's initial estimation (ICF International, 2014). The report claimed that MV's omission of numerous significant variables in its calculations contributed to considerably underestimating of the project costs, making the EfW project appear more favourable than it really would be (ICF International, 2014). By challenging, and attempting to delegitimize MV's EfW proposal, the KPMG report commissioned by Belkorp favoured the company's and the village of Cache Creek's business interests in the Cache Creek landfill, as the development of expanded EfW in MV would mean considerable reductions in waste volumes - and thus revenue - for Belkorp and the town.

FVRD, which is geographically adjacent and down-wind from MV had a broader set of concerns related to the proposed expansion of EfW in MV. As stated in FVRD's Solid Waste Management Plan Update, the region is committed to supporting sustainable WM practices, which according to FVRD precludes the integration of any combustion-based EfW technology (in contrast to the implicit approval for EfW from the province). For FVRD, EfW is fundamentally antithetical to reducing the environmental impacts of waste, and is risky from a financial and environmental standpoint. FVRD notes that EfW produces toxic air emissions, fly ash that must subsequently be landfilled in local landfills not necessarily equipped to handle incinerator ash, consumes large quantities of energy and recyclable materials, and can increase overall demand for waste (FVRD, 2015). In other words, from FVRD's perspective, EfW is a source of financial and environmental harm, fails to reduce the environmental impact associated with waste, and potentially encourages waste generation. Framing the issue as one that could undermine broader provincially-determined WM goals, FVRD is positioning itself as an advocate not just of its own interests - though this is, as we have shown, a considerable 
motivation - or NIMBYism, but rather as a protector of the goals of the governance network, namely that of diversion and disposal bans, which MV's actions could potentially undermine.

\section{Discussion and Conclusions}

The nascent but growing tendency to see waste as a potential source of energy, coupled with decreasing landfill capacity nationwide, presents challenges for governing waste in Canada (Baxter et al., 2016; Lougheed et al., 2016). We have argued that WM in MV has shifted from a traditional disposal mode of governance to a diversion mode, and finally towards a locally determined strategy that centres on waste prevention and energy recovery. However, the involvement of multiple stakeholders in WM governance across regions and the attending incongruity between locally emergent modes of governance results in a challenging patchwork of objectives and governing technologies. This fragmentation has been exacerbated by a broader neoliberal governance that has devolved most responsibility for WM to regional districts, and continues to emphasize economic concerns. Analyses of WM politics therefore require careful consideration of broader institutional relations across and between scales, something the modes of governing framework does well. In this paper, we have attempted to enhance the modes of governing framework by drawing on earlier empirical work that attends to how locally contingent interpretations of governing rationalities can result in conflict (Boyle, 2002; Murdoch, 2000). The extensive devolution of WM has resulted in a significant amount of inter-regional politics being determined by the private industries with whom regions have partnered (Howell, 2015).

Echoing Bulkeley et al., (2007), we note that the ability for regional districts to act independently and foster their own connections with private and local partners can potentially allow them the freedom to introduce innovative and locally meaningful ways of governing waste 
(Bulkeley et al., 2007, 2005). Schoenberger (2003) has noted similar benefits in her comparison of wastewater regulations in Europe and the US. In many European countries, local authorities were free to choose water treatment technologies that suited the local context and conditions, so long as water quality met national or EU regulations. In contrast, US regulations established quality standards and a blanket prescription of a specific water treatment technology that did not account for local conditions and region-specific variability. However, while local governing autonomy can contribute to political (e.g., bylaw 280) and technical innovation (e.g., EfW), as we have shown, this devolved responsibility can also be a site for the 'cultural politics' (Boyle, 2002, p. 185) that can emerge as waste and WM are 'creatively redefined' by local authorities (Bulkeley et al., 2007, p. 2750). The issue is exacerbated by the extent that EfW and the risks it inheres (Hird, 2015) extends beyond the region it serves (though similar risks also attend the global movement of solid waste to geographically distant landfills).

While regional districts are, to a large extent, autonomous, our analysis suggests that different interpretations of WM rationalities and the tendency for waste and WM infrastructure to exceed jurisdictional boundaries - along with a degree of regional inter-dependence and financial entanglement - can undermine the autonomy of those very jurisdictions. For example, higher levels of government may insert themselves in local government affairs when the actions of local governments diverge from broader governing goals in an attempt to prevent the potential dissolution and disruption of the network of WM governance (Murdoch, 2000). In MV this was made clear in 1989 with the Waste Management Act, in 2005 when the province denied MV an environmental assessment certificate for the Ashcroft landfill which would have served as an expansion to the existing Cache Creek landfill (Dalal, 2011), ${ }^{5}$ and again in 2014 when the provincial government prevented the passage of bylaw 280 . 
Rather than the 'deep' hierarchy that characterizes the diversion mode in the UK, which includes EU, national, and regional actors (Bulkeley et al., 2007), WM in Canada is characterized by a comparatively shallow hierarchy comprised of regional districts independently setting performance targets and WM plans, periodically responding to guidance or directives from the provincial government, and to an even lesser extent the federal government (Lougheed, Hird, and Rowe 2016; Darier 1996a). In the context of MV, when the province did intervene (e.g., the Waste Management Act), the outcome of the intervention was increased legitimization for the devolution of environmental responsibility. Demonstrative of the 'steering' that characterizes much contemporary governance, this intervention represents an attempt by the province to align the governing rationalities of its various independent regional districts and municipalities through legislation that requires a commitment to diversion (Murdoch, 2000). The Act both legitimized increasing the responsibility for WM placed on lower levels of government while effectively requiring greater emphasis on diversion for every regional district in the province and reducing the disparities in governing rationalities. In other words, the province prescribed both responsibility and a governing rationality for its component regional districts.

This scalar strategy is, we argue, a double-edged sword. Regional autonomy is important for ensuring freedom to govern in locally meaningful ways. However, in the case of WM, regions may have limited resources, expertise, and/or influence; thus, the scaling of WM as a regional or municipal issue in Canada can limit the feasibility of prevention and minimization strategies that require more drastic upstream structural change. Attempts at the provincial level to introduce some of these structural changes through EPR and stewardship have been slow to develop and cover only a very limited range of waste types, so their political and environmental impacts are unclear. 


\section{Funding Acknowledgement}

The authors gratefully acknowledge the financial support of the Social Sciences and Humanities Research Council of Canada (Insight Grant number 435-201300560) in conducting this research.

${ }^{1}$ Solid Waste Management Plans (SWMP) were later renamed as Integrated Solid Waste and Resource Management Plans (ISWRMP), reflecting the evolution of the meaning of waste as a potential resource.

${ }^{2}$ A whitepaper in Canada is a government document published and available to the public that outlines a set of policy challenges or priorities.

${ }^{3}$ If the disposed-of waste stream contains a specific ratio of these materials, surcharges, which vary in accordance with specific material and their quantity, are applied. Examples of these banned materials include: cardboard, recyclable paper, wires and cables, batteries, fluorescent lights and tires.

${ }^{4}$ Resource recovery from landfills primarily refers to methane gas capture, and to a much lesser extent landfill mining for minerals, metals and so on (Hird, 2017).

${ }^{5}$ The EA certificate was denied on the basis that MV ISWRMP did not demonstrate a need for expanded landfill capacity (Dalal, 2011). 


\section{References}

Allen, B. L. (2007). Environmental justice and expert knowledge in the wake of a disaster. Social Studies of Science, 37(1), 103-110. https://doi.org/10.1177/0306312706069431

Baxter, J., Ho, Y., Rollins, Y., \& Maclaren, V. (2016). Attitudes toward waste to energy facilities and impacts on diversion in Ontario, Canada. Waste Management, 50, 75-85. https://doi.org/10.1016/j.wasman.2016.02.017

BC Chamber of Commerce. (2016). 2016-2017 Policy and Positions Manual. Retrieved from http://www.bcchamber.org/sites/default/files/2016-2017\%20\%20Policy\%20and\%20Positions\%20Manual\%20-\%20Final_0.pdf

Boyle, M. (2002). Cleaning up after the Celtic Tiger: scalar "fixes" in the political ecology of Tiger economies. Transactions of the Institute of British Geographers, 27(2), 172-194. https://doi.org/10.1111/1475-5661.00048

British Columbia Ministry of the Environment. (1994). Guide to the Preparation of Regional Solid Waste Management Plans for Regional Districts (p. 76). Retrieved from http://www.llbc.leg.bc.ca/public/pubdocs/bcdocs2014/541479/guideswmplan.pdf

Bula, F. (2014a). Disposal fees drive Metro Vancouver waste out of region. Globe and Mail. Retrieved from http://www.theglobeandmail.com/news/british-columbia/disposal-feesdrive-waste-out-of-region/article19304709/

Bula, F. (2014b). Province denies Metro Vancouver's proposed garbage shipment ban. The Globe and Mail. Retrieved from http://www.theglobeandmail.com/news/britishcolumbia/province-denies-metro-vancouvers-proposed-garbage-shipmentban/article21154645/

Bulkeley, H., Watson, M., \& Hudson, R. (2007). Modes of governing municipal waste. Environment and Planning A, 39(11), 2733-2753. https://doi.org/10.1068/a38269 
Bulkeley, H., Watson, M., Hudson, R., \& Weaver, P. (2005). Governing municipal waste: towards a new analytical framework. Journal of Environmental Policy and Planning, 7(1), 1-23. https://doi.org/10.1080/15239080500251700

Carse, A. (2012). Nature as infrastructure: Making and managing the Panama Canal watershed. Social Studies of Science, 306312712440166. https://doi.org/10.1177/0306312712440166

Chhotray, V., \& Stoker, G. (2010). Governance Theory and Practice: A Cross-Disciplinary Approach. Basingstoke England; New York: Palgrave Macmillan.

Crittenden, G. (2014). Death of an incinerator: BC rejects Metro Vancouver's Bylaw 280. Solid Waste \& Recycling Magazine. Retrieved from http://www.solidwastemag.com/columns/death-incinerator-bc-rejects-metro-vancouversbylaw-280/

Dalal, S. (2011, September 9). Ashcroft Ranch Landfill Project denied EA certificate | BC Gov News. Retrieved August 14, 2016, from https://news.gov.bc.ca/stories/ashcroft-ranchlandfill-project-denied-ea-certificate

Darier, E. (1996a). Environmental governmentality: The case of Canada's green plan. Environmental Politics, 5(4), 585-606. https://doi.org/10.1080/09644019608414294

Darier, E. (1996b). The politics and power effects of garbage recycling in Halifax, Canada. Local Environment, 1(1), 63-86. https://doi.org/10.1080/13549839608725481

Dean, M. (2007). Governing Societies (1st edition). New York: Open University Press.

Dean, M. (2009). Governmentality: Power and rule in modern society. Sage Publications Limited.

European Commission. (2016, June 8). Landfill Waste. Retrieved June 14, 2016, from http://ec.europa.eu/environment/waste/landfill_index.htm 
Giroux Environmental Consulting. (2014). State of Waste Management in Canada, prepared for the Canadian Council of Ministers of Environment (No. PN1528). Retrieved from http://www.ccme.ca/files/Resources/waste/wst_mgmt/State_Waste_Mgmt_in_Canada\%2 0April\%202015\%20revised.pdf

Gordon, C. (1991). Governmental rationality: an introduction. In G. Burchell, C. Gordon, \& P. Miller (Eds.), The Foucault effect: Studies in governmentality (Vol. 1, pp. 1-52). Chicago: University of Chicago Press.

Government of British Columbia. (2014a). Municipal Solid Waste Disposal in B.C. (1990-2014). Retrieved March 2, 2017, from http://www.env.gov.bc.ca/soe/indicators/sustainability/municipal-solid-waste.html Government of British Columbia. (2014b). Province to review Metro Vancouver's solid waste management plan. Retrieved April 30, 2015, from https://news.gov.bc.ca/stories/province-to-review-metro-vancouvers-solid-wastemanagement-plan

Government of British Columbia. (2015, May 21). Changes coming to solid waste management planning process. Retrieved June 28, 2016, from https://news.gov.bc.ca/stories/changescoming-to-solid-waste-management-planning-process

Henderson, P., J. (2004). Cost-Benefit Analysis Of The Early Closure Of The Vancouver Landfill. Simon Fraser University, Burnaby, BC. Retrieved from http://summit.sfu.ca/system/files/iritems1/7760/b37793469.pdf

Hird, M. J. (2015). Waste, Environmental Politics and Dis/Engaged Publics. Theory, Culture \& Society. https://doi.org/10.1177/0263276414565717 
Hird, M. J. (2017). Burial and Resurrection in the Anthropocene: Infrastructures of Waste. In P. Harvey, C. Bruun Jensen, \& A. Morita (Eds.), Infrastructures and Social Complexity: A Routledge Companion (pp. 242-252). Routledge.

Hird, M. J., Lougheed, S. C., Rowe, R. K., \& Kuyvenhoven, C. (2014). Making Waste Management Public (or Falling Back to Sleep). Social Studies of Science, 44(5), 441465. https://doi.org/10.1177/0306312713518835

Hobson, K. (2006). Bins, Bulbs, and Shower Timers: On the "Techno-Ethics" of Sustainable Living. Ethics, Place \& Environment, 9(3), 317-336. https://doi.org/10.1080/13668790600902375

Hobson, K., \& Hill, A. (2010). Cultivating citizen-subjects through collective praxis: Organized gardening projects in Australia and the Philippines. In T. Lewis \& E. Potter (Eds.), Consuming Ethics (pp. 216-230). London: Routledge.

Howell, J. P. (2015). "Modes of governing” and solid waste management in Maui, Hawaii, USA. Environment and Planning A, 47(10), 2153-2169. https://doi.org/10.1177/0308518X15599286

ICF International. (2014). Economic Analysis of New Waste-to- Energy Facility in Metro Vancouver Submitted to Belkorp Environmental Services Inc. Retrieved from http://www.belkorp.ca/ICFIntl_MetroVancouver_WTEBusinessCaseAnalysis_2014_10_ 24.pdf

Kooiman, J. (2003). Governing as Governance. Thousand Oaks: SAGE.

Levelton Consultants Ltd. (2009). Business and Financial Assessment of Municipal Solid Waste Management in Greater Vancouver. Presented to Vancouver Board of Trade July 23, 2009. Retrieved from http://www.belkorp.ca/VBT_090723_KPMG.pdf 
Lougheed, S. C., Hird, M. J., \& Rowe, R. K. (2016). Governing Household Waste Management: An Empirical Analysis and Critique. Environmental Values, 25(3), 287-308. https://doi.org/10.3197/096327116X14598445991420

Lowndes, V. (2001). Rescuing Aunt Sally: Taking Institutional Theory Seriously in Urban Politics. Urban Studies, 38(11), 1953-1971. https://doi.org/10.1080/00420980120080871

Marres, N. (2005). Issues spark a public into being: A key but often forgotten point of the Lippmann-Dewey debate. In B. Latour (Ed.), Making things public: Atmospheres of democracy (pp. 208-217).

Melosi, M. V. (2004). Garbage in the cities: refuse reform and the environment. Pittsburgh: University of Pittsburgh Press.

Metro Vancouver. (2007). Burns Bog Ecological Conservancy Management Plan. Retrieved from http://www.metrovancouver.org/services/parks/ParksPublications/BurnsBogManagement Plan.pdf

Metro Vancouver. (2010). Integrated Solid Waste and Resource Management: a Solid Waste Management Plan. Retrieved from http://www.metrovancouver.org/services/solidwaste/SolidWastePublications/ISWRMP.pdf

Metro Vancouver. (2013). Recycling and Solid Waste Management 2013 Report. Retrieved from http://www.metrovancouver.org/services/solidwaste/SolidWastePublications/2013_Solid_Waste_Management_Annual_Summary.pdf Metro Vancouver. (2014a). 2014 Solid Waste Management Annual Summary. Retrieved from http://www.metrovancouver.org/services/solidwaste/SolidWastePublications/2014SolidWasteManagementAnnualSummary.pdf 
Metro Vancouver. (2014b). Bylaw 280. Retrieved November 25, 2014, from http://update.metrovancouver.org/services/solidwaste/planning/Bylaw280/Pages/index.as px

Metro Vancouver. (2014c). Metro Vancouver Budget in Brief. Retrieved from http://www.metrovancouver.org/about/programsbudget/BudgetPublications/2015BudgetinBrief.pdf

Murdoch, J. (2000). Space Against Time: Competing Rationalities in Planning for Housing. Transactions of the Institute of British Geographers, 25(4), 503-519. https://doi.org/10.1111/j.0020-2754.2000.00503.x

Nagel, J. (2015, December 10). Metro Vancouver halts plan to build new garbage incinerator. Retrieved April 8, 2016, from http://www.thenownewspaper.com/news/361464711.html Petts, J. (1998). Trust and waste management information expectation versus observation. Journal of Risk Research, 1(4), 307-320. https://doi.org/10.1080/136698798377079

Pierre, J., \& Peters, G. (2000). Governance, Politics and the State. St Martin's Press.

Rhodes, R. A. W. (1996). The New Governance: Governing without Government. Political Studies, 44(4), 652-667. https://doi.org/10.1111/j.1467-9248.1996.tb01747.x

Roberts, A. (1982, April 17). British Columbia Garbage battle growing. The Globe and Mail, p. P.8. Toronto, Ont.

Rutherford, S. (2007). Green governmentality: insights and opportunities in the study of nature's rule. Progress in Human Geography, 31(3), 291-307. https://doi.org/10.1177/0309132507077080 
Saltman, J. (2017, January 20). By the Numbers: Metro Vancouver waste diversion and disposal rates. Retrieved March 13, 2017, from http://vancouversun.com/news/local-news/by-thenumbers-metro-vancouver-winning-war-on-waste

Schoenberger, E. (2003). The globalization of environmental management: international investment in the water, waste-water and solid waste industries. In J. Peck \& H. W. Yeung (Eds.), Remaking the global economy (pp. 83-98).

Sinoski, K. (2010, January 6). Province approves 42-hectare expansion to Cache Creek dump. Retrieved April 30, 2015, from http://www.vancouversun.com/technology/Province+approves+hectare+expansion+Cach e+Creek+dump/2413980/story.html

Star, S. L. (1995). The politics of formal representations: Wizards, gurus, and organizational complexity. In S. L. Star (Ed.), Ecologies of knowledge: Work and politics in science and technology (pp. 88-118).

Statistics Canada. (2015). Business sector characteristics of the waste management industry, Canada, provinces and territories, every 2 years (CANSIM No. Table 153-0044). Ottawa: Statistics Canada. Retrieved from http://www5.statcan.gc.ca/cansim/a26?lang=eng\&retrLang=eng\&id=1530044\&\&pattern $=\& \mathrm{stByVal}=1 \& \mathrm{p} 1=1 \& \mathrm{p} 2=31 \&$ tabMode $=$ dataTable $\& \mathrm{csid}=$

Urban Systems. (2002). Village of Ashcroft Economic Development Strategy. Village of Ashcroft Economic Development Action Plan.

Van de Poel, I. (2008). The bugs eat the waste: What else is there to know? Changing professional hegemony in the design of sewage treatment plants. Social Studies of Science, 38(4), 605-634. https://doi.org/10.1177/0306312707088149 
Webb, S. (1999). Vancouver Bans Disposal of Paper Products. Retrieved June 26, 2016, from http://waste360.com/mag/waste_vancouver_bans_disposal 